\title{
The role of patronage in popularizing the work of Stanislav Zhukovsky
}

\section{A. Zadoia, I. Syzonenko}

\author{
Alfred Nobel University, Dnipro, Ukraine \\ John Paul II Catholic University of Lublin, Poland \\ Corresponding author. E-mail: zadoya@duan.edu.ua, 9sirena@gmail.com
}

Paper received 02.04.21; Accepted for publication 23.04.21.

\section{https://doi.org/10.31174/SEND-HS2021-254IX46-04}

\begin{abstract}
The article is devoted to the study of the peculiarities of patronage as a socio-cultural phenomenon, the forms of its manifestation in Russia at the end of the 19th and the beginning of the 20th centuries, as well as the influence on the formation of the creative fate of a particular person - the Polish artist Stanislav Yulianovich Zhukovsky (1873-1944), who, by the will of historical destinies, in the period under review lived on the territory of the Russian Empire in Moscow. The role of individual patrons of art in supporting the artist through the acquisition of his paintings is analyzed. The fate of individual works of the artist, which have survived to this day thanks to the private collections of Russian patrons of art, has been investigated.
\end{abstract}

Keywords: S.Yu. Zhukovsky, patronage, sponsorship, private collections, museums.

Introduction. Patronage is the most important social institution that purposefully contributes to the preservation and development of cultural heritage, as well as the spiritual development of society through culture. Patronage means charity. The concept of a patron originates from the name of Gaius Cilnius the Maecenas, who was an approximate of the Emperor Augustus in ancient Rome. He carried out the private and diplomatic orders of the emperor, and also provided patronage and material assistance to such poets as Virgil and Horace. Today it is necessary to distinguish between such concepts as patronage and sponsorship. Sponsorship is contractual financing or investment of material and technical resources by both an individual and a legal entity (or group of persons) in any activity. This support is similar to charitable support, but it has an important significant difference - the selfless nature of the help.

Unlike sponsorship, patronage is gratuitous assistance; patrons are people who systematically and voluntarily donate money and funds for the construction and operation of various cultural structures (temples, theaters, museums) that help the creative intelligentsia. Thus, patronage differs from sponsorship by the absence of selfish goals. Historically, philanthropy presupposes charity primarily in the field of artistic culture. The social responsibility of business is the responsibility of the subjects and their voluntary contribution to the development of society in the social, economic, environmental and other spheres. Social responsibility is an ethical principle, not a rule, duty is internal to oneself, and is based on moral norms and values. Russian lawyer and statesman K.P. Pobedonostsev wrote: "Money would come to life if the soul that owns it would revive and would become in the hands of a person a powerful instrument of fruitful productivity and rational beneficence" [1, p. 143]. Based on this, the social responsibility of a business is, first of all, the responsibility imposed on the business, often in the form of requirements. Patronage is always a voluntary activity, it is not an obligation, but one's own desire to support talents and culture.

Review of Publications on the Topic. A lot of scientific research is devoted to the problems of patronage. Researchers are looking at various aspects of this problem. In particular, D. Bearfield is trying to revise the basic conceptual provisions that underlie the study of patronage. The author calls for a reexamination of the concept based on developments found in the field of anthropology. In an effort to generate future scholarship, the author introduces a typology of patronage styles based on this reexamination [2].

A group of authors investigate patronage from the standpoint of assessing its role in the political system of Latin America. Analysis of the features of the manifestation of patronage showed its dependence on the form of government [3].

The study by Miklós Szanyi is devoted to the study of the role of patronage in the economic life of European countries. The author argues that patronage in a distorted form, which is characteristic of countries with a young democracy, has as its purpose to obtain additional rent at the expense of budgetary funds [4].

A significant place among scientific works on patronage is occupied by publications on its role in the development of art and, in particular, fine art. It is possible to name a number of works by Russian researchers, which deal with charity and patronage in pre-revolutionary Russia [5]. At the same time, most often, research is conducted from the standpoint of assessing the role of specific individuals in the formation of museum values, expositions or exhibitions. There are practically no studies that would be devoted to assessing the role of patronage in the life of certain artists.

The purpose of the article. The purpose of our study is to clarify the features of patronage as a socio-cultural phenomenon, the forms of its manifestation in Russia at the end of the 19th and the beginning of the 20th centuries, as well as the influence on the formation of the creative fate of a particular person - the Polish artist Stanislav Yulianovich Zhukovsky (1873-1944), who, by the will of historical destinies, in the period under review lived on the territory of the Russian Empire in Moscow.

Materials and methods. The main source of information for writing an article were monographs and scientific articles on the research topic. Archival materials from a number of museums in the Russian Federation, Poland and Ukraine were widely used.

The results of the study. It has become a generally accepted truth today that many museums are based on private collections. Thanks to the selfless activity of collectors, the richest museum fund has developed not only in museums in Russia, Poland, Ukraine, Belarus, but also in many museums around the world. Behind the passion for collecting and patronage, in our opinion, there is a humanistic mission - the unification of mankind and its introduction to the 
eternal. Whole epochs pass, empires collapse, states disappear and appear, generations and peoples replace each other. But through the depths of centuries, extremely fragile creations are preserved and come to us - the cultural creations of the human spirit. Therefore, collecting and patronage can be defined as a manifestation of the highest wisdom and beauty of the human spirit.

What are the motives for patronage? According to the statements of many patrons, this is responsibility before God and people, a noble opportunity to remove one's guilt for wealth. Patronage for the persons of the reigning house and the nobility is a way of glorifying their dynasty. For persons representing industrial, commercial and other strata of society, patronage acts as a family, clan tradition, a special concept of honor and personal conscience.

The types and forms of manifestation of patronage and collecting in the Russian Empire at the beginning of the 20 th century were very diverse. Coming into contact with the environment of wealthy patrons and collectors, S. Zhukovsky performed only one professional action: he worked intensively on his creative methods, created paintings and actively exhibited at exhibitions of creative associations of which he was a member.

The visiting card of S. Zhukovsky has always been his talent, which deserved the highest appreciation and investment of appropriate funds. Interest in the work of S. Zhukovsky was shown by:

-museums (both private and state);

- members of the ruling imperial house of Emperor Alexander III;

- representatives of the aristocratic circles of the Russian Empire;

- representatives of merchant, trade and industrial circles of the Russian society;

- mediated by managers and marketers of foreign firms promoting their products and advertising on the Russian market.

One of the collectors of Stanislav Zhukovsky's works was the Alexander III Museum in St. Petersburg. Empress Maria Feodorovna (Maria Sophia Frederica Dagmar, Princess of Denmark (1847-1928)) was engaged in charitable activities. The Empress headed the Red Cross Society in Russia, orphanages, hospitals. Together with the Empress, Alexander III created museum funds at the expense of the royal treasury, visited together at the opening of exhibitions, they bought works of artists directly from exhibitions or ordered artists. So, in 1898 for the Museum of Alexander III, a student of the Moscow School of Painting, Sculpture and Architecture Stanislav Zhukovsky acquired the landscape "Forest. (First Snow)" [6]. The following canvases were purchased directly from the author from exhibitions for the Museum of Alexander III: "At the Mill" (1904), acquired from the author in 1905 from the II Exhibition of Paintings of the Union of Russian Artists, in St. Petersburg [7]; "Poetry of an old noble house" (1912), acquired from the author in 1913 from the X exhibition of paintings by the Union of Russian Artists in St. Petersburg [8]. Currently in the State Museum of Russian Art in St. Petersburg (formerly the Museum of Alexander III) is one of the largest and most valuable collections of paintings by Stanislav Zhukovsky in the world.

The second museum in the Russian Empire, which acquired the works of S. Zhukovsky, was the Rumyantsev
Museum. By decree of Nicholas I, the Rumyantsev Museum was opened in St. Petersburg in 1831 and became the country's first public private museum. It was based on the collection of Count Nikolai Rumyantsev - State Chancellor, diplomat, philanthropist, historian. Everyone, without exception, could visit the museum. For the first 30 years the museum was located in St. Petersburg, then it was moved to Moscow. In Moscow, the Museum was housed in the Pashkov House. The grand opening took place in 1861. The public could visit it 4 days a week, a ticket cost 10 kopecks, and on Sunday admission was free. The main patron of the arts was the Imperial House and the Emperor himself.

S. Zhukovsky, while still a student at the Moscow School of Painting, Sculpture and Architecture and participating in student exhibitions, attracted the attention of the staff of the Rumyantsev Museum with his canvases. So, in 1897, from the XX Exhibition of paintings by students of the Moscow School of Painting, Sculpture and Architecture, S. Zhukovsky's landscape "Frowned (Autumn)" (1897) was purchased [9]. In 1899 the landscape "Evening. Sheds and a Shock of Hay" (1899), and in 1911 a beautiful landscape full of nostalgia "The Last Asters" was purchased from the author. The canvas was purchased directly from the author from the XXXX Traveling Exhibition of Pictures of the Association of Traveling Art Exhibitions [10].

The founder of the Theater Museum in Moscow in 1894 was the merchant Alexei Alexandrovich Bakhrushin (1865-1929). A. Bakhrushin, like other collectors, acquired paintings by $\mathrm{S}$. Zhukovsky directly from the author's exhibitions. These are the paintings "Living Room" (19131914) and "Spring Rays. Interior "(1913), which are still kept in the State Central Museum after named A.A. Bakhrushin (Moscow, Russia) [11].

In 1896-1898, diligence, dedication and great love for creativity brought the student of the Moscow School of Painting, Sculpture and Architecture, Stanislav Zhukovsky, his first fame. But the young and ambitious artist understands that he can receive full recognition only when his works take their place in the collection of the Tretyakov brothers. Courage and self-confidence allowed the young artist to turn directly to P. Tretyakov.

The first painting by S. Zhukovsky, acquired by the philanthropist P. Tretyakov, was called "Spring Evening" (1896) and was shown at the XXV Traveling Exhibition of Paintings in 1897 [12].

P. Tretyakov closely follows the artist's success and regularly buys his works for the Tretyakov Gallery. So, in 1901, P. Tretyakov acquired the landscapes "Spring Day" (1901) from S. Zhukovsky, in 1906 - "Autumn Evening" (1905), from the XXXIV Traveling Exhibition in 1912 "Joyful May" (1912).

Patron of art and collector P. Tretyakov with his regular acquisitions not only financially supports the young artist, but also creates for him a train of fame and an aura of success, the highest recognition by acquiring and placing a whole collection of the artist's works in the renowned Tretyakov Gallery.

The circle of patrons and collectors of S. Zhukovsky included both representatives of the aristocratic circles of the Russian Empire and representatives of merchant, industrial, banking circles of Russian society. 
The Society of Friends of the Rumyantsev Museum included Prince Pavel Andreevich Putyatin (1837-1919), an admirer of S. Zhukovsky's artistic talent and an active collector of the artist's works. In the collection of Prince P.A. Putyatin, there was a significant number of landscapes by S. Zhukovsky, but after the revolution of 1917 , a tragic fate befell them, like their owner. The fate of the museum collection of Prince Putyatin remains unclear. From the inscriptions on the paintings that have survived to this day, there is evidence of the stay of S. Zhukovsky in the estate and park of the Bologoye estate. Until now, several works by S. Zhukovsky have come down, which were purchased by Prince P.A. Putyatin directly from the artist. These are the following works:

"White House" (1906) (Sketch for the painting of the same name in 1906 from the Astrakhan Picture Gallery; on the back of the painting there is an inscription by the author: A sketch from nature for the painting Park is exposed from the collection of drawings by Prince PA Putyatin (cyrylica)). Currently, the sketch is in the collection of S.Ya. Feldshtein (Cheboksary, Russia);

"Corner of a hut in winter" (On the back of the picture, the author's inscription: Stanislav Yulianovich Zhukovsky (cyrylica)). From the collection of paintings by Prince P.A. Putyatin. Chaikovskaya Picture Gallery (Chaikovsk, Russia);

"House with a front garden in winter" (1909-1910). On the reverse side of the painting the author's inscription: $S$. Zhukovsky (cyrylica) From the collection of paintings by Prince P.A. Putyatin. Chaikovskaya Art Gallery (Chaikovsk, Russia).

The presence of S. Zhukovsky's canvases in museums of modern Ukraine in many cases is associated with the collections of prominent Ukrainian collectors and patrons of the late XIX and early XX centuries, and among them Pavel Ivanovich Kharitonenko (1852-1914).

Personal friends and collectors of S. Zhukovsky's paintings were the brothers Sergei Pavlovich Ryabushinsky (1872-1936) and Mikhail Pavlovich Ryabushinsky (18801960). Since 1900 M.P. Ryabushinsky is fond of collecting. In 1909, his collection includes 100 paintings by Western European and Russian artists. The collection included such well-known canvases as "The Demon" by M. Vrubel, "Japanese Doll" by BM. Kustodieva, "The Singer of the Cafe - Shantana" by E. Degas, "Dam" (1909) by S. Zhukovsky.

S. Zhukovsky and S.P. Ryabushinsky were tied by friendly relations, often friends met at the Lubenkino estate and as participants at exhibitions. The appearance of S. Zhukovsky's painting "Sleepless Night. Daybreak" (1903) at the XXXII Traveling Exhibition of paintings caused a flurry of enthusiasm. S. Zhukovsky considered this work one of his best works. At the request of S.P. Ryabushinsky, he sold this painting to him in 1904. Today this painting is on permanent display at the Tver Picture Gallery (Tver, Russia). From the entire collection of S.P. Ryabushinsky also miraculously survived S. Zhukovsky's landscape "Autumn Evening" (1905). In 1961 it was transferred to the Tambov Art Gallery, where it is currently located (Tambov, Russia).

Thanks to the patronage and collecting activities of the Samara merchant of the 1st guild Pavel Ivanovich Shikhobalov (1870-1929), three paintings by S. Zhukovsky are currently kept in the Samara Art Museum (Samara, Russia).

P. Shikhobalov and his wife V. Shikhobalova were likeminded people - they were united by common interests in culture, literature, and art. Collectors were especially attracted by the works of young artists - works by S. Vinogradov, N. Bogdanov-Belsky, S. Zhukovsky appeared in their collection. S. Zhukovsky, as a rule, gave the Shikhobalovs the opportunity to acquire their paintings directly from exhibitions. This is how the artist's paintings were acquired:

"Sad Thoughts" (1908. Repetition of the 1907 painting from the collection of G. Burshtein). Currently, the canvas is on permanent display at the Samara Art Museum. Entered the museum in 1918 from the requisitioned collection of P. Shikhobalov;

"Cloudy Day" (1900). Currently, the canvas is in the museum collection of the Samara Art Museum;

"Early Spring" (1910). Currently, the canvas is in the museum collection of the Samara Art Museum.

Warm friendly relations connected S. Zhukovsky with one of the most famous married couples in Moscow, engaged in patronage and collectors. They are Girshman Vladimir Osipovich (1867-1936) and Henrietta Leopoldovna (1885-1970). The Girshman collection included the following works by S. Zhukovsky:

"Spring Water" (1898). Study for the painting of the same name in 1896 from the Museum of Alexander III (now the State Russian Museum, St. Petersburg), from the State Tretyakov Gallery was transferred to the Novotorzhsky Museum of Local Lore, from which it disappeared in 1932 and its location is not known;

"Bright night. Moonlit Night in Winter" (1900). It was donated by V. Girshman to the Rumyantsev Museum. Currently located in the Tver Regional Art Museum (Tver, Russia);

"Dacha. Terrace "(1918-1919). Entered the State Tretyakov Gallery in 1918 from the collection of V. Girshman.

The collection of works included, perhaps, a larger number of paintings, but it is difficult to establish precisely at the present time, since during the so-called "nationalization" of collections, some of them did not reach state museums and galleries.

One of the prestigious magazines "Capital and manor. Magazine of a beautiful life", which was published in St. Petersburg. It was an illustrated, informational, cultural, historical and biographical magazine, one of the best examples of pre-revolutionary periodicals. The magazine was published with a time interval of two weeks.

The magazine "Capital and manor" was published in St. Petersburg, but distributed in Moscow, Warsaw, Kharkov, Odessa, Riga and other cities. It was another coup of the sponsor's marketing policy - the names of cities and addresses of factory warehouses were given on the FIAT advertisement. Such sponsorship, as a manifestation of marketing innovations of Western European market policy in Russia, had its real manifestation for the first time and the fact of the opening and successful professional activity of the magazine "Capital and manor" in the context of these marketing operations confirms this.

The well-known critic S.N. Kondakov published in the magazine "Capital and manor" four publications with objective and positive judgments about the work of $\mathrm{S}$. 
Zhukovsky, noting his innovative character of creative evolution, the individual world of poetry in the captured and subtly captured states of nature. The appearance of such evaluative publications in such a prestigious popular magazine undoubtedly served as yet another proof of the high and deserved respect and appreciation of the artist's work.

A very interesting look at the current situation from the standpoint of modern marketing theory can be. The wellknown company sponsors the publication of the magazine and uses its pages to promote its brand among potential buyers in the regions where the publication is distributed. However, given the peculiarity of the target audience (the readers of the magazine are mainly representatives of the upper secular society and wealthy entrepreneurs, manufacturers, bankers, merchants), there is a need to demonstrate the connection between the publication (and through it the sponsor) with some popular and authoritative personalities in this environment. Today this technique is called "icon marketing", which is mainly used for the promotion of territories.

With a certain degree of convention, it can be assumed that FIAT has used icon marketing more than 100 years ago, placing a publication about selected artists in a magazine sponsored by it. The inclusion of S. Zhukovsky among these chosen ones is another confirmation of his popularity and authority among the readers of the magazine.

Thus, the analysis showed that patronage in Russia at the end of the 19th and the beginning of the 20th centuries played an important role not only in the development of fine art in general, but also helped individual artists to form as creative personalities. Many patrons, having considered the future talented artist in a young student Stanislav Zhukovsky, acquired his works for their private collections, which eventually became the basis of the most famous art museums. It is thanks to patronage that in the 21 st century there is an opportunity to admire the work of this outstanding Polish artist.

\section{REFERENCES}

1. Charity in Russia as a social institution: history, formation, development / Under. ed. B.V. Ostanin. SPb: Faces of Russia, 2003. - $640 \mathrm{p}$.

2. Bearfield D. What Is Patronage? A Critical Reexamination // Public Administration Review 69(1). - January 2009. - PP. 64 - 76. DOI: 10.1111/j.1540-6210.2008.01941.x

3. Panizza F., Larraburu C.R.R., Scherlis G. Unpacking Patronage: The Politics of Patronage Appointments in Argentina's and Uruguay's Central Public Administrations // Journal of Politics in Latin America. - Vol 10, Issue 3, 2018. - PP.59-98. https://doi.org/10.1177/1866802X1801000303

4. Miklós Szanyi. The emergence of patronage and changing forms of rent-seeking in East Central Europe // PostCommunist

Economies, 2019

DOI: $10.1080 / 14631377.2019 .1693738$

5. Benefactors and patrons of the past and present [Text]: dictionary-reference book from A to Z / auth.-comp. M. L. Makalskaya, N. N. Bobrovskaya. - M.: Delo and Service, 2003. - 207

p.

6. Catalog of the XXVI Traveling Exhibition of Pictures. The Association of Traveling Art Exhibitions. - Kharkov, 1898.

7. Catalog II Exhibition of the Union of Russian Artists, Moscow, Petersburg 1904-1905.

8. Catalog X Exhibition of the Union of Russian Artists, Moscow, Petersburg 1911-1912.

9. Catalog XX Exhibition of paintings by students of the School of Painting, Sculpture and Architecture, Moscow 1897

10. Catalog XXXX Traveling exhibition of paintings by the Association of Traveling Art Exhibitions, Moscow, Petersburg 1911-1912.

11. Catalog XXXII Traveling exhibition of paintings by the Association of Traveling Art Exhibitions, Moscow, Petersburg, Kharkov, 1904-1905.

12. Catalog XXV Traveling Exhibition of Pictures of the Association of Traveling Art Exhibitions, Moscow, St. Petersburg, Kiev, 1897. 